\title{
SCREENING OF RICE PROTEINS USING 2-D GELS AFTER INOCULATION WITH Rhizotonia solani
}

\section{Detección de proteínas de arroz utilizando geles 2-D después de la inoculación con Rhizotonia solani}

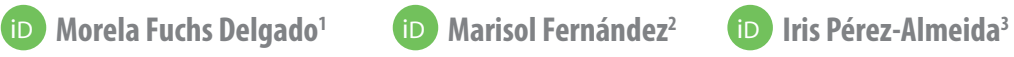 \\ 1 National Institute for Agricultural Research, INIA, Venezuela \\ 2 Proteomics Facility, Centro Nacional de Biotecnología, Spain \\ ${ }^{3}$ Universidad Tecnológica ECOTEC, Ecuador \\ Correspondencia: \\ PhD. Iris Perez Almeida \\ iperez@ecotec.edu.ec
}

\section{ABSTRACT}

Sheath blight caused by Rhizotonia solani is described as the second major disease affecting rice. Genetic resistance to $R$. solani the ideal control measure is hampered because of the difficulty in identifying adequate resistance sources under typical selection conditions. Proteomic analysis techniques using two-dimensional gels (2D-PAGE) allow the study or monitoring of global changes in protein expression under normal and stress conditions. In this work, we compared rice leaves protein expression patterns of two Venezuelan varieties 12, 24 and $48 \mathrm{~h}$ after inoculation with $R$. solani. Approximately 400 and 300 protein spots stained with Sypro Ruby were reproducibly resolved across gel replicates, for PALMAR and FONAIAP-2000, respectively. Forty proteins out of a total 49 were identified for PALMAR variety, with thirty-two up-regulated protein spots and 8 down-regulated. Twenty-six proteins out of a total 33 were identified for FONAIAP-2000 variety, with seven up-regulated protein spots and 19 down-regulated. RuBisCo was the protein most identified (48\% and 82\% of the detected proteins for PALMAR and FONAIAP-2000, respectively). Other identified proteins showing variations were ATPase beta subunit, UDP-glucose anthocyanin 5-O-glucosyltransferase, RNA-binding protein, putative transkelotase 1, putative ferredoxin-NAPD $(\mathrm{H})$ oxide-reductase, and putative $33 \mathrm{kDa}$ oxygen evolving protein photosystem II. Based on our results, rice response to $R$. solani could be described where energy is required to induce a defense and it is supplied by proteins involved in energy metabolism. According to this, proteomic could provide information and insights on the response of rice to challenge with $R$. solaniand other pathogens.

Key words: rice, Rhizoctonia solani, resistance proteins, 2-D PAGE.

\section{RESUMEN}

El tizón de la vaina causado por Rhizotonia solani se describe como la segunda enfermedad importante que afecta al arroz. La resistencia genética a $R$. solani, la medida de control ideal, se ve obstaculizada debido a la dificultad de identificar fuentes de resistencia adecuadas en condiciones típicas de selección. Las técnicas de 
análisis proteómico que utilizan geles bidimensionales (2D-PAGE) permiten el estudio o seguimiento de cambios globales en la expresión de proteínas en condiciones normales y de estrés. En este trabajo, comparamos los patrones de expresión de proteínas en hojas de arroz de dos variedades venezolanas 12, 24 y 48 h después de la inoculación con $R$. solani. Se resolvieron de forma reproducible aproximadamente 400 y 300 spots de proteína teñidas con Sypro Ruby, para PALMAR y FONAIAP-2000, respectivamente. Se identificaron cuarenta proteínas de un total de 49 para la variedad PALMAR, con treinta y dos spots proteicos regulados en incremento y 8 regulados en menor expresión. Se identificaron 26 proteínas de un total de 33 para la variedad FONAIAP-2000, con siete spots proteicos regulados en aumento y 19 regulados en decrecimiento. RuBisCo fue la proteína más identificada (48\% y $82 \%$ de las proteínas detectadas para PALMAR y FONAIAP-2000, respectivamente). Otras proteínas identificadas que mostraron variaciones fueron la subunidad beta de ATPasa, UDPglucosa antocianina 5-O-glucosiltransferasa, proteína de unión al ARN, transkelotasa 1 putativa, ferredoxina-NAPD $(H)$ óxido-reductasa putativa, y proteína generadora de oxígeno putativa del fotosistema II, de $33 \mathrm{kDa}$. Con base en nuestros resultados, la respuesta del arroz a R. solani podría describirse como que requiere energía para inducir una defensa y se suministra por proteínas implicadas en el metabolismo energético. Según esto, la proteómica podría proporcionar información y conocimientos sobre la respuesta del arroz al desafío con $R$. solaniy otros patógenos.

Palabras clave: Arroz, Rhizoctonia solani, proteínas de resistencia, 2-D PAGE

\section{INTRODUCTION}

Rice is not only an important agricultural resource but also a model plant for biological research. Oryza sativa is one of the most important crops in the world; it is the main staple food of more than half of the world's population (FAO, 2018). Since rice has a genome significantly smaller than those of other cereals, it is an ideal model plant for genetic and molecular studies (Liu et al. 2018).

Rhizoctonia solani is a formidable fungal pathogen for rice (Oryza sativa) and numerous other plant species, but very little is known about this hostfungus interaction at the protein level (Prathi et al. 2018). Sheath blight disease (ShB), caused by $R$. solani, is a major constraint to high grain yield and quality in many rice-growing regions of the world (Molla et al. 2020; Cardona \& Delgado, 2016) and has increased in appreciable way by the high densities of rice crops in Venezuela, which create a favorable environment for development of sheath blight (González-Vera et al. 2010; Zhang et al. 2019). General symptoms of sheath blight include necrotic, dark, reddish-brown, elliptical or oval shaped areas on the leaf sheath, leaf blade and culm. R. solani is believe to secrete various toxins, the most notable of which is the RS phytotoxin, a carbohydrate molecule containing glucose, mannose, N-acetylgalactosamine and $\mathrm{N}$-acetylglucosamine (Molla et al. 2020). Usually, plants respond to pathogens by complex defense responses. It was found strategies against fungi by production of substances like phytoalexins, proteins related with pathogenity, oxidated phenols and other compounds. Characterizing the rice defense response for ShB resistance some studies have concluded that a jasmonic acid (JA)-induced resistance pathway (Zhang et al. 2019; Karmakar et al. 2017; Wang et al. 2015) and a salicylic acid (SA)-mediated systemic acquired resistance pathway (Zhang et al. 2019; Kouzai et al. 2018; Molla et al. 2016) might influence the resistance of rice to $R$. solani. These two important pathways, which form part of the defense system in rice, have common defense-related and pathogenesis-related proteins such as chitinases (Karmakar et al. 2017; Karmakar et al. 2016; Richa et al. 2017), glucanases (Yadav et al. 2015; Lee et al. 2006), and OsWRKY transcription factors (Wang et al. 2015). 
Most varieties growing around the world are susceptible to $R$. solani, although moderate to high levels of tolerance have been reported. To date, no major ShB resistance genes or rice cultivars exhibiting complete resistance to $R$. solani have been reported, likely because of the polygenic nature of ShB resistance (Molla et al. 2020; Zhang et al. 2019). The application of chemicals remains the major method for controlling rice ShB despite the overuse of chemical fungicides contributes to increased health risks and environmental problems. Although ShB exerts a substantial impact on rice production in many regions of the world, limited information is available on response to infection by $R$. solani at the protein or genetic level. Looking for genetic resistance to $R$. solani has been one of the control alternatives studied for this pathogen, however this option has not been totally successful because complexities to identify the causes of resistance and the little defined differences between genotypes under typical selection conditions. ShB is difficult to manage because of the wide host range, rapid variability, and long survival time in the soil (Taheri \& Höfte, 2007). Pyramiding diverse ShB resistance alleles from QTLs differing in their level of moderate resistance by marker-assisted selection can efficiently enhance the resistance of rice to R. solani (Yadav et al. 2015; Hossain et al. 2016). The analysis of proteins using highresolution two-dimensional polyacrylamide gel electrophoresis (2D-PAGE) is the most direct approach for defining gene function. Therefore, here we focus on proteomics as a tool for the comprehensive analysis of plant response to infection with $R$. solani.

Proteomic approaches using two-dimensional gel electrophoresis (2-DE) enable the study or to monitor the global challenges in the protein expression in tissues that are under stress conditions or not. It is a valuable tool in providing functional information regarding abiotic and biotic responses. Recently Wu et al. (2016), used it to study rice responses to drought; while Li et al. (2012), studied the interaction between rice and the blast fungus Magnaporthe grisea, finding differentially abundant proteins implicated in various functions, including defense, antioxidative stress enzymes, and signal transduction.

Understanding the genetic mechanisms of plant disease resistance against this pathogen will benefit the development of improved varieties with $R$. solani resistance enormously. To investigate the rice- $R$. solani interaction, we conducted a proteomic analysis in Venezuelan resistant and susceptible rice cultivars after $R$. solani infection. The primary objectives of this research were to monitor the global defense response of rice leaves sheath proteins to $R$. solani infection and to identify proteins significantly expressed in response to $R$. solani infection that can serve as candidates for resistance or susceptibility in future studies of rice-fungal interactions and in the development of new, disease resistant varieties.

\section{MATERIALS AND METHODS Plant material and inoculation}

Rice seeds of two Venezuelan varieties (Palmar and FONAIAP-2000) were pre-germinated in Petri dishes with wet paper towels, transferred to plastic bags filled with sterile soil $(\approx 5000 \mathrm{~g})$ and then placed in a growth room maintained at $26{ }^{\circ} \mathrm{C}$ and $70 \%$ relative humidity with a $12 / 12 \mathrm{~h}$ day $\left(200 \mu \mathrm{E} \mathrm{m}^{-2} \mathrm{~s}^{-1}\right) /$ night in the Biotechnology Unit at INIA - CENIAP (National Institute for Agricultural Research - National Center for Agriculture \& Husbandry Research), Maracay, Venezuela. Palmar and FONAIAP-2000 have shown intermediate resistance and susceptibility to Rhizoctonia solani respectively, in previous greenhouse and field experiments.

A total of 9 rice plants per cultivar were inoculated by placing a single sclerotium of Rhizoctonia solani on the pod of the leaves of sixty-day-old plants, since the panicle's exsertion initiation phase (R4) has shown higher susceptibility to the infection by ShB. Control plants did not receive any inoculation treatment. Experiments were performed with 3 replicates per each treatment.

\section{Protein extraction}

Rice leaves blades from each treatment were 
collected at 12,24 and $48 \mathrm{~h}$ after inoculation. Fresh weight was recorded, leaves were homogenized with liquid nitrogen, and dissolved in lysis buffer II (8.4 M urea, 2.4 M thiourea, 5\% (w/vol) CHAPS, 2 mM TCEP-HCL and 1\% (v/v) carrier ampholytes, $\mathrm{pH}$ 3-10), during $4 \mathrm{~h}$ with agitation. Samples were centrifuged at $14000 \mathrm{rpm}$ for $15 \mathrm{~min}$ at RT. The resultant supernatant was precipitated with Clean-Up (GE) and dialyzed with Plus One Microdialysis Kit (GE). Protein determination was performed with BIO-RAD (RC DC Protein Assay) Kit. A non-inoculated control sample was also processed.

\section{Electrophoresis and staining}

Each sample was rehydrated $(100 \mu \mathrm{g})$ with $7 \mathrm{M}$ urea, $2 \mathrm{M}$ thiourea, $4 \%$ (w/v) CHAPS, $0.5 \%$ (v/v) ampholites 3-11 NL, $10 \mathrm{mM}$ DTT for $1 \mathrm{~h}$ and applied in $18 \mathrm{~cm}$ IPG strips, 3-11 NL, previously rehydrated with $7 \mathrm{M}$ urea, $2 \mathrm{M}$ thiourea, $2 \%(\mathrm{w} / \mathrm{v})$ CHAPS, $0.5 \%(\mathrm{v} / \mathrm{v})$, ampholites 3-11 NL, $12 \mu \mathrm{mL}^{-1}$ DeStreak. Isoelectric focusing was carried out with the IPGphor IEF System by increasing voltage as follows: $300 \mathrm{~V} \mathrm{~h}^{-1}$ for $3 \mathrm{~h}$, gradient increase from 300 to $1000 \mathrm{~V}$ for $6 \mathrm{~h}$, gradient increase from 1000 to $8000 \mathrm{~V}$ for $3 \mathrm{~h}, 8000 \mathrm{~V} \mathrm{~h}^{-1}$ for $3 \mathrm{~h}$ until a total $42.500 \mathrm{~V}$ was reached. After IEF separation, the strips were equilibrated two times for 10 min with 50 mM Tris- $\mathrm{HCl}$ (pH 8.8), 6 M urea, 30 \% glycerol, 2 $\%$ SDS, and trace amounts of bromophenol blue. The first equilibration solution contained $1 \%$ DTT. The second equilibration solution contained $4 \%$ iodoacetamide. Second dimension was performed with $12.5 \%$ polyacrylamide gels.

The gels were stained using SYPRO Ruby Protein Gel Stain from Sigma: first the gel was fixed in 10 $\% \mathrm{MeOH} / 7 \%$ acetic acid for $1 \mathrm{~h}$, incubated in SYPRO Ruby staining solution for $3 \mathrm{~h}$ to overnight, washed in 10\% MeOH/ $7 \%$ acetic acid two times for 30 min, washed two times in water for 10 min. Stained gels were scanned in a TyphoonTM Variable Mode Imager with the appropriate conditions. The images were analyzed with the ImageMaster 2D-Platinum Software V5.5.

\section{Mass spectrometry}

Differentially expressed proteins were excised from 2D gels with the spot picker (GE), deposited in 96-well plates and processed automatically in a Proteineer DP (Bruker Daltonics, Bremen, Germany). For protein digestion gel plugs were washed with $50 \mathrm{mM}$ ammonium bicarbonate and treated with acetonitrile before reduction with 10 $\mathrm{mM}$ DTT in $25 \mathrm{mM}$ ammonium bicarbonate and alkylation with $55 \mathrm{mM}$ iodoacetamide in $50 \mathrm{mM}$ ammonium bicarbonate. Proteins were digested with modified porcine trypsin (sequencing grade; Promega, Madison WI) at a final concentration of $15 \mathrm{ng} \mathrm{ul}^{-1}$ in $25 \mathrm{mM}$ ammonium bicarbonate for 4 $\mathrm{h}$ at $37^{\circ} \mathrm{C}$. Peptides were eluted from gel pieces with $0.5 \%$ trifluoroacetic acid in water for $30 \mathrm{~min}$ at $25^{\circ} \mathrm{C}$.

The resulting peptides were analyzed by MALDITOF mass spectrometry; $0.5 \mu \mathrm{l}$ of matrix solution (1 $\mathrm{mg} \mathrm{mL} \mathrm{mL}^{-1}$ cyano-4-hydroxycinnamic acid in $33 \%(\mathrm{v} / \mathrm{V})$ aqueous acetonitrile and $0.1 \%$ trifluoroacetic acid ( $\mathrm{V} / \mathrm{V}$ ) was added onto a 600 $\mu \mathrm{m}$ AnchorChip ${ }^{\text {TM }}$ MALDI target (Bruker Daltonics) and allowed to dry at RT. A $0.5 \mu$ aliquot of each peptide mixture was then deposited onto matrix spots and dried out at RT.

MALDI peptide mass fingerprinting for each protein was acquired automatically on a Bruker Reflex IV MALDI-TOF mass spectrometer (Bruker Daltonics) equipped with SCOUTTM source in positive ion reflector mode; ion acceleration voltage was set as $23 \mathrm{kV}$. Spectra were acquired by the software FlexControl 2.4 (Bruker Daltonics) and then processed using the Flex Analysis 2.4 software (Bruker Daltonics). The equipment was first externally calibrated employing protonated mass signals from a peptide mixture covering the $1000-3500 \mathrm{~m} / \mathrm{z}$ range. For peak lists generation each spectrum was then internally calibrated with two known trypsin autoproteolysis peptides, specifically 842.510 and $2211.105 \mathrm{Da}$, to reach a typical mass measurement accuracy of \pm 30 ppm in the $800-3000 \mathrm{~m} / \mathrm{z}$ range. All known contaminants (other trypsin-derived peptides and keratins) were excluded during the process. The parameters used to analyze the data were a signal-to-noise threshold of 20 and the resolution higher than 4000. 


\section{Database searches}

For protein identification, the measured tryptic peptide masses were batch processed and searched against the non-redundant NCBI database (National Center for Biotechnology Information) using the software Mascot 2.1 (www. matrixscience.com; Matrix Science, London, UK) through the Biotools 2.0 interface (Bruker Daltonics). Search parameters were set as follows: carbamidomethyl cystein as fixed modification by the treatment with iodoacetamide, oxidized methionines as variable modifications, peptide mass tolerance of $80 \mathrm{ppm}$ and 1 missed cleavage site allowed. In all protein identifications, the probability mouse scores were greater than the minimum score fixed as significant.

\section{RESULTS AND DISCUSSION}

Approximately 400 and 300 spots stained with Sypro Ruby were reproducibly resolved for PALMAR and FONAIAP-2000 varieties respectively, on all six 2-D gels used in the comparison analysis for each variety, which consisted of three biological replications for two treatments of infection (inoculation vs noninoculation). Biological replications gave a high correlation for sensitivity as well as for volume of the spots in all gels for each variety (Figure 1); these data demonstrated that all 2-D images are highly reproducible and can be used for further quantitative analysis. Protein spots were reproducibly resolved across all gels, resulting in similar protein spot locations across replications (Figures 2, 4). Analysis of the separated proteins by 2D-PAGE from leaves of two rice varieties with Image master 2D Platinum (GE) image analysis software, revealed proteins that were only presents in the control leaves after $48 \mathrm{~h}$ of inoculation with $R$. solani, proteins that were only seeing in the inoculated leaves, proteins that were in higher abundance either in the control or in the inoculated leaves; and proteins that decreased in the inoculated leaves.

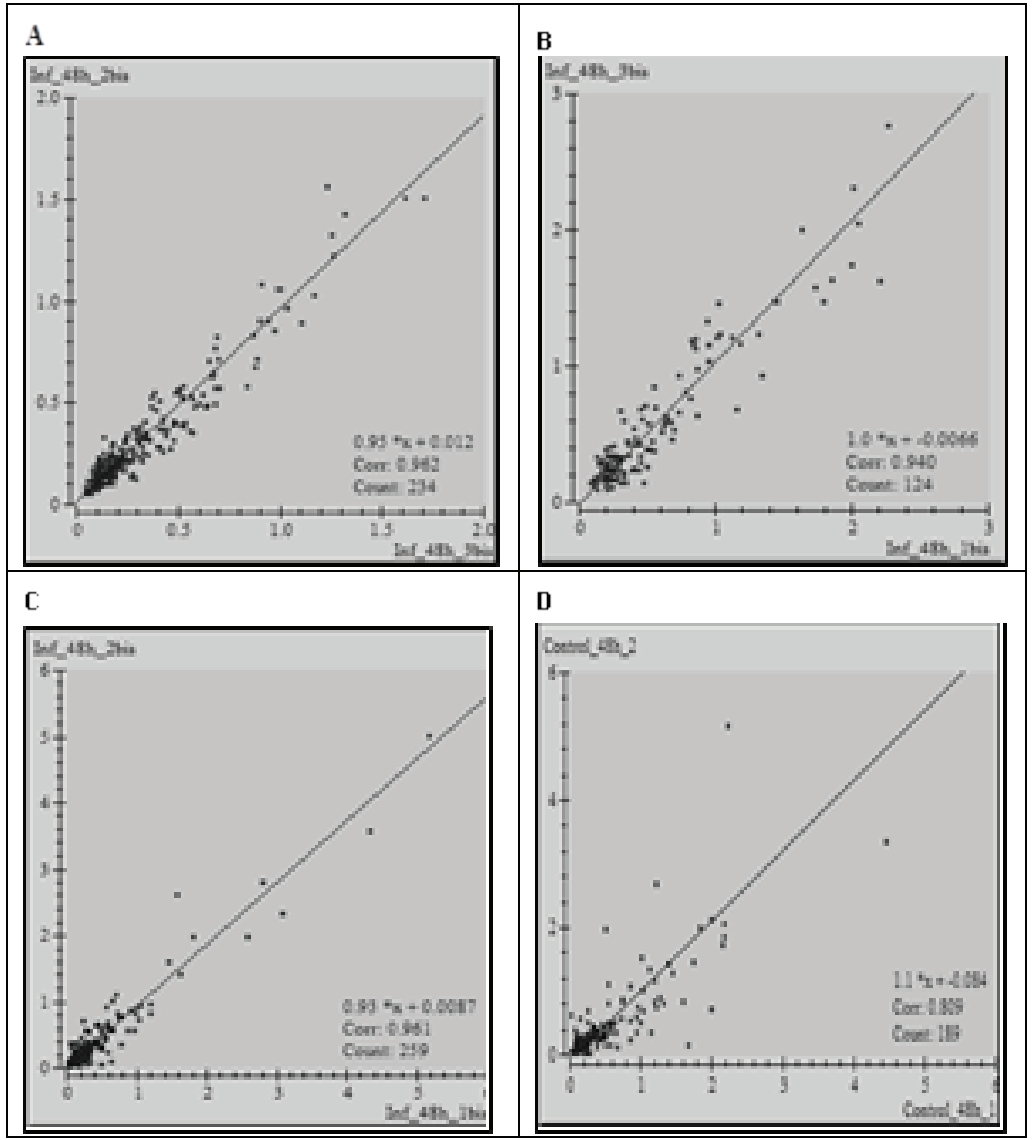

Figure 1. Correlation by intensity for PALMAR (A) or FONAIAP-2000 (B) or by volume for PALMAR (C) or FONAIAP-2000 (D) of spots in some of the 2D-gels. 2-D images are highly reproducible and can be used for further quantitative analysis. 

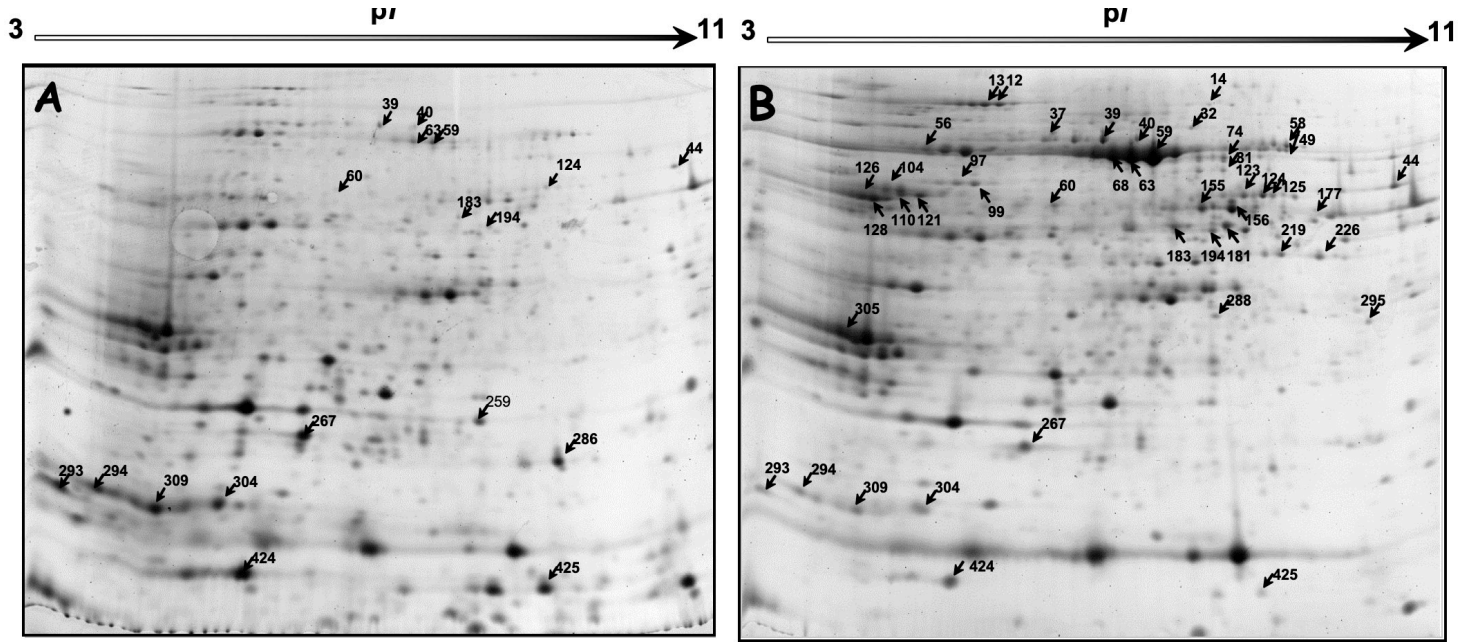

Figure 2. Sypro-Ruby-stained 2-DE PAGE gels of rice leaf sheath proteins extracted from inoculated and noninoculated Palmar line. A) Control; B) Inoculated leaves, both after $48 \mathrm{~h}$. Numbers refer to proteins with increased or decreased levels in infected leaves. Proteins were separated with an IPG strip, pH 3-11, and 12\% linear polyacrylamide LDS-PAGE. Gel images were acquired with an TyphoonTM Variable Mode Imager. Circled proteins were identified by MALDI-TOF mass spectrometry. Spot numbers were assigned in an arbitrary fashion.
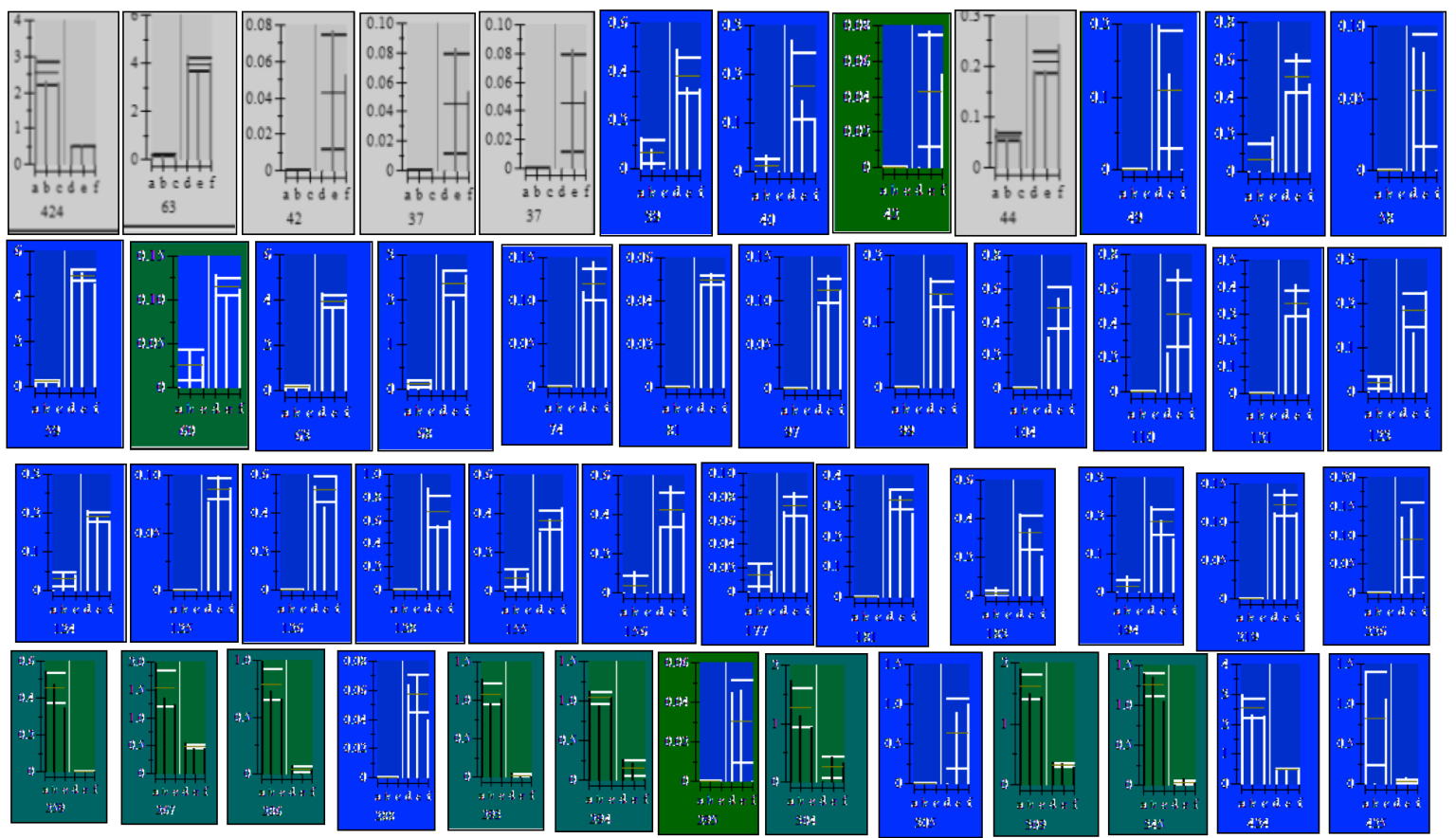

Figure 3. Graphical presentation of spot volumes for all 49 differentially expressed proteins, in each gel of the PALMAR variety. $\mathrm{a}, \mathrm{b}, \mathrm{c}$ corresponding to controls and d, e, f corresponding to inoculated leaves with $R$. solani. Determinations were obtained with the Image Master 2D Platinum imaging software(GE). 

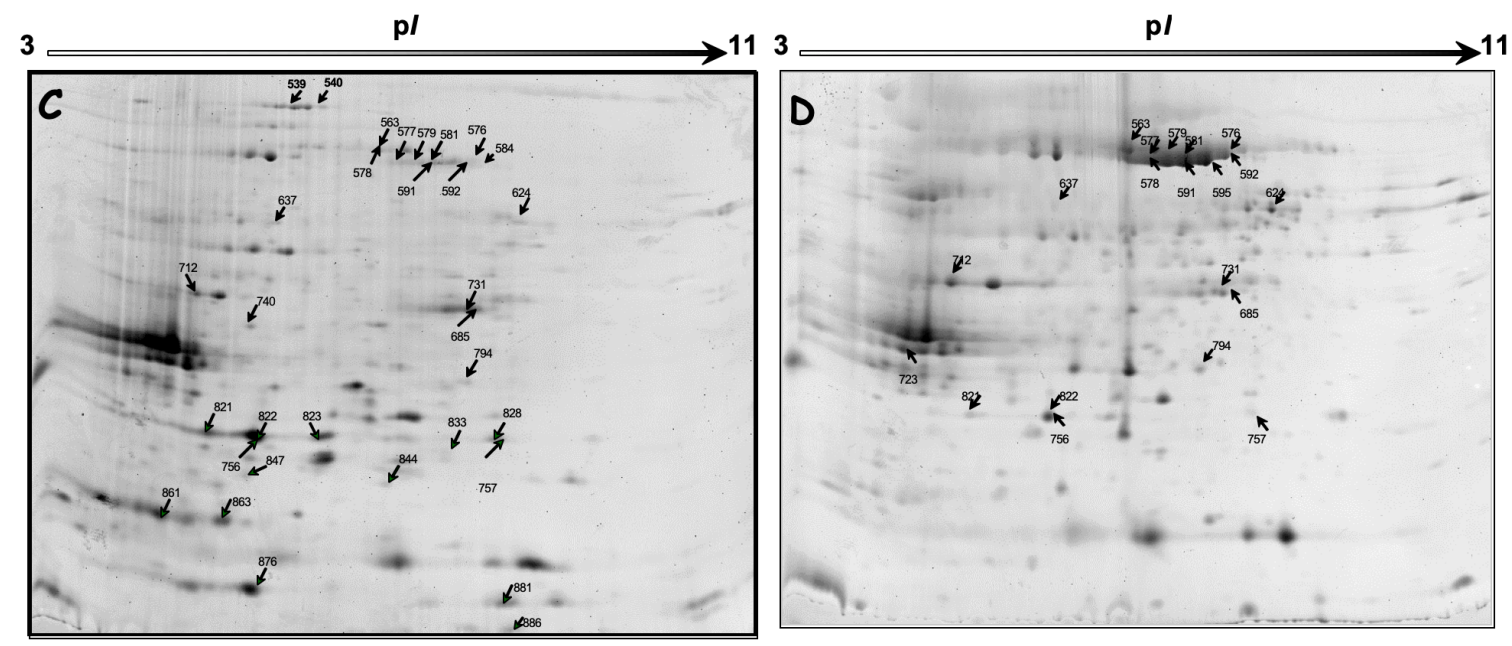

Figure 4. Sypro-Ruby-stained 2-DE PAGE gels of rice leaf sheath proteins extracted from inoculated and non-inoculated FONAIAP-2000 variety. A) Control; B) Inoculated leaves, both after $48 \mathrm{~h}$. Numbers refer to proteins with increased or decreased levels in infected leaves. Proteins were separated with an IPG strip, pH 3-11, and 12\% linear polyacrylamide LDSPAGE. Gel images were acquired with an TyphoonTM Variable Mode Imager. Circled proteins were identified by MALDI-TOF mass spectrometry. Spot numbers were assigned in an arbitrary fashion.
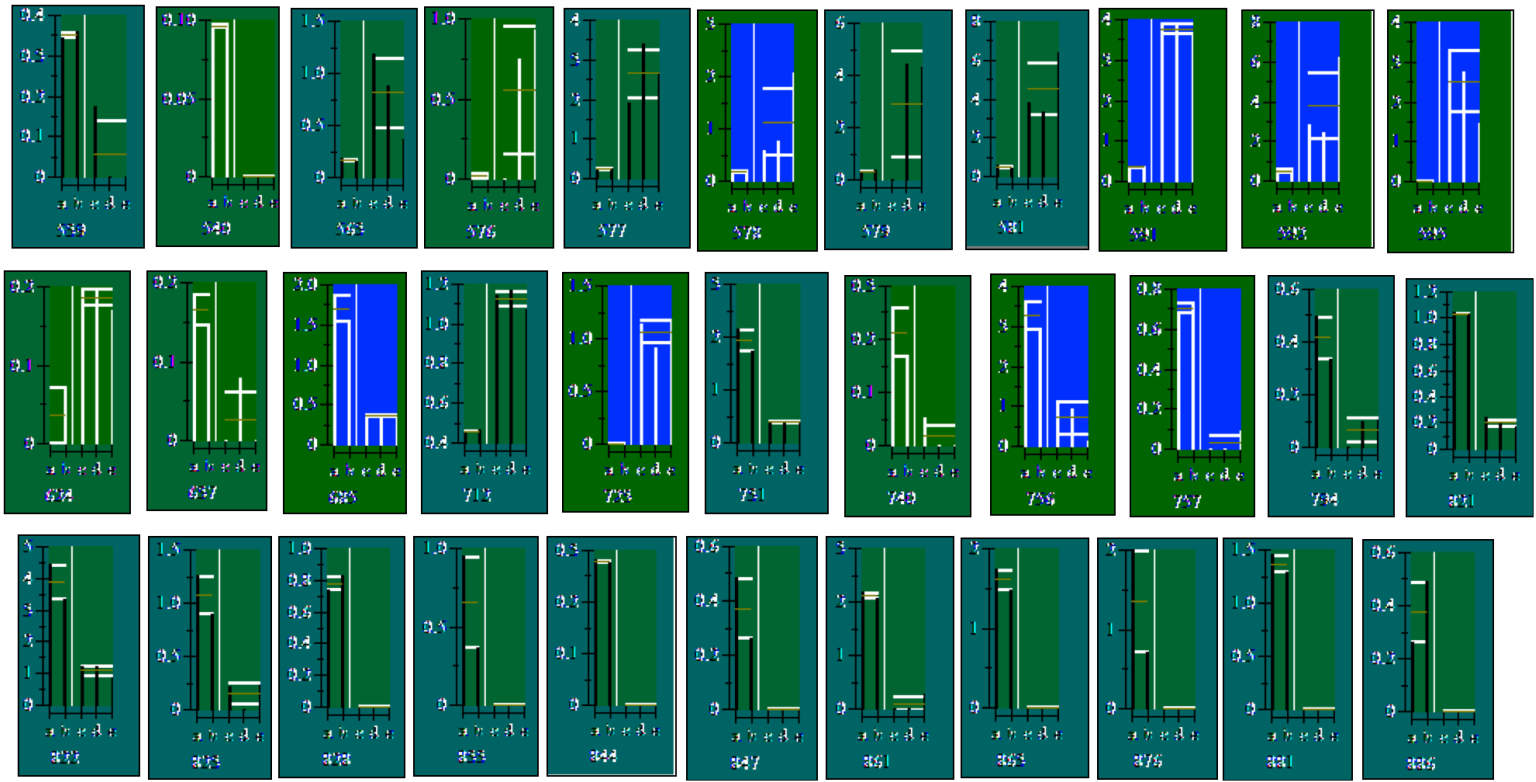

Figure 5. Graphical representation of spot volume for all 33 expressed differentially proteins, in each gel of the FONAIAP-2000 variety. a, b, c corresponding to controls and d, e, f corresponding to inoculated leaves with $R$. solani. Determinations were obtained with the Image Master 2D Platinum imaging software(GE). 
Table 1

Differentially expressed proteins in PALMAR variety. Numbers refer to spots numbers indicated in Figure 2. The abundance, accession number, title, MW, pl and score of the proteins identified are shown

\begin{tabular}{|c|c|c|c|c|c|c|}
\hline Spot & Vol. Ratio & Accession & Title & MW & $\mathrm{pl}$ & Score \\
\hline 12 & increased & gi|55775372 & putative transketolase 1 [Oryza sativa (japonica cultivar-group)] common name: Japanese rice & 69407 & 5.43 & 99 \\
\hline $\begin{array}{l}13 \\
14\end{array}$ & $\begin{array}{l}\text { increased } \\
\text { increased }\end{array}$ & $\begin{array}{l}\text { gi|55775372 } \\
\text { gil51536102 }\end{array}$ & putative transketolase 1 [Oryza sativa (japonica cultivar-group)] common name: Japanese rice & 69407 & 5.43 & 78 \\
\hline 32 & increased & gi|34894800 & putative dihydrolipoamide dehydrogenase precursor [Oryza sativa (japonica cultivar-group) & 53009 & 7.21 & 76 \\
\hline 37 & increased & gi|50931037 & OSJNBa0061C08.5 [Oryza sativa (japonica cultivar-group)] & 55687 & 5.95 & 144 \\
\hline 39 & increased & gi|50931037 & OSJNBa0061C08.5 [Oryza sativa (japonica cultivar-group)] & 55687 & 5.95 & 156 \\
\hline 40 & increased & gi|50931037 & OSJNBa0061C08.5 [Oryza sativa (japonica cultivar-group)] & 55687 & 5.95 & 103 \\
\hline 42 & increased & gi|50931037 & OSJNBa0061C08.5 [Oryza sativa (japonica cultivar-group)] & 55687 & 5.95 & 112 \\
\hline 44 & increased & $\mathrm{NI}$ & & & & \\
\hline 49 & increased & gi|33440012 & catalase [Oryza sativa (japonica cultivar-group)] & 56998 & 6.93 & 123 \\
\hline 56 & increased & gi|49615002 & ATPase beta subunit [Oryza nivara]wild rice & 53978 & 5.38 & 92 \\
\hline 58 & increased & $\mathrm{NI}$ & & 43917 & 6.42 & 143 \\
\hline $\begin{array}{l}59 \\
60\end{array}$ & $\begin{array}{l}\text { increased } \\
\text { increased }\end{array}$ & $\begin{array}{l}\text { gi } \mid 54303876 \\
\mathrm{NI}\end{array}$ & ribulose-1,5-bisphosphate carboxylase/oxygenase large subunit [Buergersiochloa bambusoides] & 43917 & 6.42 & 143 \\
\hline 63 & increased & gi|57283874 & ribulose bisphosphate carboxylase large chain [Oryza sativa] & 53331 & 6.23 & 201 \\
\hline 68 & increased & gi|61378612 & ribulose-1,5-bisphosphate carboxylase/oxygenase large subunit [Australopyrum velutinum] & 52228 & 6.23 & 170 \\
\hline 74 & increased & gi|552516 & ribulose 1,5-bisphosphate carboxylase & 50225 & 6.41 & 80 \\
\hline $\begin{array}{l}81 \\
97\end{array}$ & $\begin{array}{l}\text { increased } \\
\text { increased }\end{array}$ & $\begin{array}{l}\text { gil } 54303878 \\
\text { gil } 50910077\end{array}$ & $\begin{array}{l}\text { ribulose-1,5-bisphosphate carboxylase/oxygenase large subunit [Distichlis spicata] } \\
\text { translational elongation factor Tu [Oryza sativa (japonica cultivar-group)] }\end{array}$ & $\begin{array}{l}44264 \\
50610\end{array}$ & $\begin{array}{l}6.29 \\
6.19\end{array}$ & $\begin{array}{l}163 \\
105\end{array}$ \\
\hline 99 & increased & gi|50910077 & translational elongation factor Tu [Oryza sativa (japonica cultivar-group)] & 50610 & 6.19 & 124 \\
\hline 104 & increased & $\mathrm{NI}$ & & & & \\
\hline 110 & increased & $\mathrm{NI}$ & & & & \\
\hline 121 & increased & $\mathrm{NI}$ & & & & \\
\hline 123 & increased & gi|15788117 & ribulose 1,5-bisphosphate carboxylase/oxygenase large subunit [uncultured chlorophyte alga] & 21857 & 6.84 & 86 \\
\hline 124 & increased & gi|57283874 & ribulose bisphosphate carboxylase large chain [Oryza sativa] & 53331 & 6.23 & 123 \\
\hline 125 & increased & $\mathrm{NI}$ & & & & \\
\hline 126 & increased & gi|62733297 & RuBisCO activase small isoform precursor [Oryza sativa (japonica cultivar-group)] & 52394 & 5.59 & 138 \\
\hline 128 & increased & gi|62733297 & RuBisCO activase small isoform precursor [Oryza sativa (japonica cultivar-group)] & 52394 & 5.59 & 151 \\
\hline 155 & increased & gi|54303878 & ribulose-1,5-bisphosphate carboxylase/oxygenase large subunit [Distichlis spicata] & 44264 & 6.29 & 92 \\
\hline 156 & increased & gi|54303878 & ribulose-1,5-bisphosphate carboxylase/oxygenase large subunit [Distichlis spicata] & 44264 & 6.29 & 111 \\
\hline 177 & increased & $\mathrm{NI}$ & & & & \\
\hline 181 & increased & gi|16943753 & atp synthase, beta subunit [Trillium erectum] & 53721 & 5.16 & 76 \\
\hline 183 & increased & gi|4115559 & UDP-glucose:anthocysnin 5-O-glucosyltransferase [Perilla frutescens var. crispa] & 51512 & 4.93 & 76 \\
\hline 194 & increased & gi|77554826 & RNA binding protein, putative [Oryza sativa (japonica cultivar-group)] & 44815 & 9.06 & 118 \\
\hline 219 & increased & $\mathrm{NI}$ & & & & \\
\hline 226 & increased & gi|34897776 & putative ferredoxin-NADP(H) oxidoreductase [Oryza sativa (japonica cultivar-group)] & 40381 & 8.72 & 122 \\
\hline 259 & only in control & gi|22711949 & ribulose 1,5 -bisphosphate carboxylase/oxygenase large chain [Chaetosphaeridium globosum] & 53099 & 6.00 & 82 \\
\hline 267 & decreased & gi|18920474 & ribulose 1,5-bisphosphate carboxylase/oxygenase large subunit [Chaetosphaeridium globosum] & 48539 & 6.26 & 68 \\
\hline 286 & only in control & gil54303892 & ribulose-1,5-bisphosphate carboxylase/oxygenase large subunit [Phaenosperma globosa] & 42984 & 6.75 & 82 \\
\hline 288 & increased & gi|50931037 & OSJNBa0061C08.5 [Oryza sativa (japonica cultivar-group)] & 55687 & 5.95 & 86 \\
\hline 293 & only in control & gil 56966765 & Chain W, Crystal Structure Of Activated Rice Rubisco Complexed With 2-Carboxyarabinitol-1,5-Bisphosphate & 15091 & 5.89 & 62 \\
\hline 294 & decreased & gi|57283874 & ribulose bisphosphate carboxylase large chain [Oryza sativa] & 53331 & 6.23 & 91 \\
\hline 295 & increased & gi|50928489 & OSJNBa0041A02.10 [Oryza sativa (japonica cultivar-group)] & 37956 & 8.83 & 71 \\
\hline 304 & decreased & gi|50935687 & hypothetical protein [Oryza sativa (japonica cultivar-group)] & 85047 & 8.78 & 78 \\
\hline 305 & increased & gi|77554374 & Ribulose bisphosphate carboxylase, small subunit [Oryza sativa (japonica cultivar-group)] & 15111 & 6.59 & 61 \\
\hline 309 & decreased & gi|56966764 & Chain E, Crystal Structure Of Activated Rice Rubisco Complexed With 2-Carboxyarabinitol-1,5-Bisphosphate & 53401 & 6.13 & 106 \\
\hline 345 & decreased & gi|1881525 & ribulose-1,5-bisphosphate carboxylase, large subunit [Spermacoce tenuior] & 52279 & 6.04 & 80 \\
\hline 424 & increased & gil16565257 & ribulose 1,5-bisphosphate carboxylase large subunit [Palisota ambigua] & 52339 & 6.00 & 86 \\
\hline 425 & increased & gi|4038707 & ribulose-1,5-bisphosphate carboxylase/oxygenase small subunit [Aegilops bicornis] & 18746 & 9.16 & 80 \\
\hline
\end{tabular}

with protein name, NCBI accession number, MW/pl and identity scores. In FONAIAP-2000 variety, 33 protein spots were detected whose relative abundance varied in response to R. solani infection (Figures 4, 5), but only 26 could be identified; 7 upregulated protein spots and 19 downregulated, detailed in Table 2 with protein name, NCBI accession number, MW/pl and identity scores. 


\section{Table 2}

Differentially expressed proteins in FONAIAP-2000 variety. Numbers refer to spots numbers indicated in Figure 3. The abundance, accession number, title, MW, pl and score of the proteins identified are shown

\begin{tabular}{|c|c|c|c|c|c|c|}
\hline Spot & Vol. Ratio & Accession & Title & MW & $\mathrm{pl}$ & Score \\
\hline 539 & decreased & gi|55775372 & putative transketolase 1 [Oryza sativa (japonica cultivar-group)] & 69407 & 5.43 & 177 \\
\hline 540 & only in control & $\mathrm{NI}$ & & & & \\
\hline 563 & increased & $\mathrm{NI}$ & & & & \\
\hline 576 & increased & gi|2961262 & ribulose-1,5-bisphosphate carboxylase [Coussarea macrophylla] & 53171 & 5.88 & 199 \\
\hline 577 & increased & gi|54303878 & ribulose-1,5-bisphosphate carboxylase/oxygenase large subunit [Distichlis spicata] & 44264 & 6.29 & 128 \\
\hline 578 & increased & $\mathrm{NI}$ & & & & \\
\hline 579 & increased & gi|17232974 & ribulose-1,5-biphosphate carboxylase [Lemna trisulca] & 50052 & 6.29 & 174 \\
\hline 581 & increased & gi|294394 & ribulose 1,5-bisphosphate carboxylase/oxygenase & 53445 & 6.04 & 151 \\
\hline 591 & increased & $\mathrm{NI}$ & & & & \\
\hline 592 & increased & gi|61378612 & ribulose-1,5-bisphosphate carboxylase/oxygenase large subunit [Australopyrum velutinum] & 52228 & 6.23 & 230 \\
\hline 595 & only in infect & gi|42795561 & ribulose 1,5-bisphosphate carboxylase/oxygenase; rbcL [Oryza sativa (japonica cultivar-group)] & 54294 & 6.33 & 179 \\
\hline 624 & decreased & gi|1488586 & ribulosebiphosphate carboxylase [Hordeum brachyantherum] & 45761 & 6.28 & 169 \\
\hline 637 & decreased & gi|11559110 & RuBisCO large subunit [Schippia concolor] & 53082 & 6.24 & 70 \\
\hline 685 & decreased & gi|42795561 & ribulose 1,5-bisphosphate carboxylase/oxygenase; rbcL [Oryza sativa (japonica cultivar-group)] & 54294 & 6.22 & 164 \\
\hline 712 & increased & gi|34914480 & putative $33 \mathrm{kDa}$ oxygen evolvingprotein of photosystem II [Oryza sativa (japonica cultivar-group)] & 35068 & 6.10 & 84 \\
\hline 723 & increased & $\mathrm{NI}$ & & & & \\
\hline 731 & decreased & $\mathrm{NI}$ & & & & \\
\hline 740 & only in control & gi|20143564 & ATPase alpha subunit, 3'-partial [Oryza sativa (japonica cultivar-group)] & 29355 & 5.27 & 86 \\
\hline 756 & decreased & gi|38532311 & ribulose-1,5-bisphosphate carboxylase/oxygenase large subunit [Pseudotaxus chienii] & 47255 & 6.29 & 83 \\
\hline 757 & decreased & gi|44894760 & ribulose-1,5-bisphosphate carboxylase/oxygenase large subunit [Potamogeton gramineus x Potamogeton perfoliatus & 19625 & 7.88 & 90 \\
\hline 794 & decreased & gi|1050738 & ribulose-1,5-bisphosphate carboxylase [Pentodon pentandrus] & 52235 & 6.04 & 76 \\
\hline 821 & decreased & gi|26986095 & ribulose-1,5-bisphosphate carboxylase/oxygenase [Lygodium heterodoxum] & 49124 & 6.26 & 93 \\
\hline 822 & decreased & $\mathrm{NI}$ & & & & \\
\hline 823 & only in control & gi|37543331 & ribulose-1,5-bisphosphate carboxylase/oxygenase [Coleochaete pulvinata] & 47710 & 6.30 & 68 \\
\hline 828 & only in control & gi|305308 & ribulose 1,5 -bisphosphate carboxylase & 52789 & 6.34 & 84 \\
\hline 833 & only in control & gi|1870136 & ribulose-1,5-bisphosphate carboxylase, large subunit [Stawellia dimorphantha] & 52228 & 6.18 & 118 \\
\hline 844 & only in control & gi|4567235 & putative phosphatidylinositol/phophatidylcholine transfer protein [Arabidopsis thaliana] & 43182 & 8.65 & 70 \\
\hline 847 & only in control & gi|1488586 & ribulosebiphosphate carboxylase [Hordeum brachyantherum] & 45761 & 6.28 & 95 \\
\hline 861 & only in control & gi|1332531 & ribulose-biphosphate carboxylase large subunit [Kniphofia uvaria] & 52157 & 6.10 & 117 \\
\hline 863 & only in control & gi|13242849 & ribulose bisphosphate carboxylase large subunit [Orbignya barbosiana] & 53449 & 6.23 & 97 \\
\hline 876 & only in control & gi|56966764 & Chain E, Crystal Structure Of Activated Rice Rubisco Complexed With 2-Carboxyarabinitol-1,5-Bisphosphate & 53401 & 6.13 & 78 \\
\hline 881 & only in control & gi|61378685 & ribulose-1,5-bisphosphate carboxylase/oxygenase large subunit [Thinopyrum bessarabicum] & 52169 & 6.04 & 71 \\
\hline 886 & only in control & gi|51493536 & ribulose-1,5-bisphosphate carboxylase/oxygenase large subunit [Elymus solanderi] & 50235 & 6.40 & 123 \\
\hline
\end{tabular}


Others authors have found induction and increase of proteins in rice plants in presence of pathogens fungus. For instance, Lee et al (2006) reported 21 protein spots whose relative abundance varied in the response of the resistant or susceptible genetic background to R. solani infection; while Kim et al (2005) found 8 proteins resolved on the 2-DE gels which were induced or increased in the inoculated leaves with Magnaphorte grisea.

Matrix-assisted laser desorption/ionization-time of flight analysis of these differentially displayed proteins showed an increase in the proteins related with energetic metabolism. RuBisCo was the protein most identified $(48 \%$ and 82 $\%$ of the identified proteins for PALMAR and FONAIAP-2000 varieties, respectively). RuBisCo is well known to be the most abundant protein in rice leaves; a high content of RuBisCo proteins was found (Zhao et al. 2005), with multiple p/values and MW, and found not to contain degradation products, moreover, multiple fragments of RuBisCo large subunit were generated during growth and shown different growth-dependent patterns. Relative abundance reported (Lee et al. 2006) of three distinct RuBisCO large subunits and a precursor were detected in the inoculated resistant genotype at 2-3-fold higher levels than in the corresponding susceptible treatments. Degradation of RuBisCo might be highly susceptible to a number of exogenous, endogenous, and even chloroplastic proteases, such as trypsin, chymotrypsin, proteinase $K$, and papain. However, the mechanism by which the proteases are activated is still not well understood. A hypothesis could be that reactive oxygen species (ROS) trigger RuBisCo degradation, once ROS accumulates in chloroplasts, RuBisCo may be modified, facilitating its subsequent degradation by proteases (Marín-Navarro \& Moreno, 2006). Indeed, rice leaves contains proteins in excess of that required for leaves function, for instance RuBisCo is a very inefficient enzyme and a small decrease in Rubisco content is a useful strategy for photosynthesis improvements at elevated $\mathrm{CO} 2$ concentration and leads to greater biomass production (Kanno, Suzuki \& Makino, 2017).
Other proteins identified that show increased under infection, were ATPase beta subunit, catalase, UDP-glucose anthocyanin 5-O-glucosyltransferase, RNA binding protein, putative transketolase 1, putative formatetetrahydrofolate ligase, putative ferredoxinNADP(H) oxidoreductase, putative $33 \mathrm{kDa}$ oxygen evolving protein of photosystem $\|$, putative dihydrolipoamide dehydrogenase precursor. And proteins that show decreased were putative transketolase 1, ATPase alpha subunit, 3'-partial and putative phosphatidylinositol/ phosphatidylcholine transfer protein, all in FONAIAP-2000.

We identified a putative high-molecular-weight catalase protein (spot:49) whose amount was markedly increased under infection; it is implicated in electron transport, response to oxidative stress. We identified some other proteins, that were upregulated by infection, such as dihydrolipoamide dehydrogenase (spot:32) is the common component of the three a-ketoglutarate, and the branched-chain a-keto acids, and is also involved in the glycine cleavage system. RNA-binding proteins (spot:194) have been known to function in control of mRNA turnover and translational efficiency, splicing of pre-mRNAs, and post-transcriptional regulation of the expression of chloroplast gene (Merchante, Stepanova \& Alonso, 2017).

We also identified two protein spots (spots:12, 13) as putative transketolase 1, whose amount was increased under infection in PALMAR but in FONAIAP-2000 decreased (spot: 539). This enzyme transfers a carbohydrate residue with two carbon atoms from F6P to glyceraldehyde-3phosphate. OSJNBBa0661C08.5 (spots: 37, 39, 40, $42,288,295)$ also increased, are involved in proton transporting ATPase complex, catalytic core F (spot 1), ATP binding hydrogen-transporting ATPase activity, rotational mechanism hydrolase activity, acting and acid anhydrides, catalyzing transmembrane movement of substances, metal ion binding, nucleotide binding. ATPase beta subunit (spots: 56,181 ) whose produce ATP from ADP in presence of a proton gradient across 
the membrane, also are increased. Translation elongation factor Tu (spots 97, 99), also increased, involucrated in GTP binding, nucleotide binding, translation elongation factor activity, protein biosynthesis, translation elongation. UDPglucose anthocyanin 5-O-glucosyltransferase (spot: 183) with transferase activity, transferring hexosyl groups, metabolism. Putative ferredoxinNADP $(H)$ oxidoreductase (spot:226) with oxidoreductase activity, electron transport. ATPase alpha subunit, 3'-partial (spot:740) is only in control and it's involved in protontransporting two-sector ATPase complex, ATP binding, hydrogen-transporting ATPase activity, rotational mechanism, hydrolase activity, ATP synthesis coupled proton transport, ion transport, proton transport. Putative phosphatidylinositol/ phosphatidylcholine transfer protein (spot:844) with transporter activity also is only in control.

Photosynthesis is amongst the plant cell functions that is highly sensitive to high temperature stress and is often inhibited before other cell functions are impaired. The primary sites of targets of high temperature stress are Photosystem II (PSII), ribulose-1,5-bisphosphate carboxylase/ oxygenase (Rubisco) while Cytochrome b559 (Cytb559) and plastoquinone (PQ) are also affected (Mathur, Agrawal \& Jajoo, 2014). We identified one spot (spot:712) corresponding to the oxygen evolving protein of Photosystem II, whose amounts were increased by the infection in FONAIAP-2000. The oxygen evolving protein is involved in oxygen evolution and Photosystem II stability. The oxygen evolving complex protein was also found to be induced in the leaf blade (Abbasi \& Komatsu, 2004). Interestingly, a severe stress condition, such as ozone and sulfur dioxide fumigation, results in suppression of the oxygen evolving protein (Kim et al. 2004; Agrawal et al. 2002). These results suggest that the protein related to oxygen evolution is also differentially regulated by environmental factors.

Although the direct interaction and response against the infection occurs in the infected area, it can be impossible to distinguish the response between rice proteome and $R$. solani proteome when the proteins from $R$. solani have homology with rice proteins (Lee et al. 2006) owing to the fact that the protein and nucleotide database of R. solani is limited and the protein identification method with MS technology used in this study is absolutely dependent on the protein and nucleotide database.

The functional categories of the proteins were identified as defense, energy, metabolism, cell structure, signal transduction and functional unknown protein. Based on results from this study, the rice response to $R$. solani may be described where energy required to induce a defense was supplied by proteins involved in energy metabolism.

Photosynthesis is the core process upon which all plant and animal life depends. Plants have the capacity to fix $\mathrm{CO}_{2}$ and to assimilate this fixed carbon into other tissues. The ability to convert fixed carbon in other tissues is especially pertinent to the human population in plants whose biomass is used for food or industrial purposes. Since the process of photosynthesis takes place in the leaf, it is an indispensable factory of the biological world, this photosynthetic activity is loss in infected leaves; it would be interesting to identify proteins associated with response to infection by $R$. solani. Photosynthetic improvement and biomass enhancement by more strictly controlling Rubisco content in response to future environmental changes will hopefully be achieved (Kanno, Suzuki \& Makino, 2017).

\section{CONCLUSIONS}

Results from these experiments indicate that proteomics methods will providenewinformation and insights into the response of rice challenged with $R$. solani. Analysis of the separated proteins by 2D-PAGE from leaves of two rice varieties with Image master 2D Platinum (GE) image analysis software, revealed after $48 \mathrm{~h}$ of inoculation with R. solani, changes in the electrophoretic profiles. RuBisCo was the protein more abundant and many times identified. Energy required to induce a defense was supplied by proteins involved in energy metabolism. 


\section{BIBLIOGRAPHIC REFERENCES}

Abbasi F M, Komatsu(2004). S A proteomic approach to analyze salt-responsive proteins in rice leaf sheath, Proteomics, 4 (2004) 2072-2081. doi: 10.1002 / pmic.200300741

Agrawal G K, Rakwal R, Yonekura M, Kubo A., Saji $H,(2002)$ Proteome analysis of differentially displayed proteins as a tool for investigating ozone stress in rice (Oryza sativa L.) seedlings. Proteomics, 2 (2002) 947-959. DOI: 10.1002 / 1615-9861 (200208) 2: $8<947$ :: aid-prot947> 3.0.co; 2-j

Cardona R, Delgado N. (2016) Inheritance of resistance to the rice (Oryza sativa L.) fungus Rhizoctonia solani in two rice populations in Venezuela, Revista de la Facultad de Agronomía Universidad del Zulia 33 (2016) 311-324.

FAO (2018) Rice Market Monitor available at: http://www.fao.org/ publications/card/en/c/I9243EN/

González-Vera A D, Bernardes-De-Assis J, Zala M, McDonald B A, Correa-Victoria $F$ et al, Divergence between sympatric rice- and maize-infecting populations of Rhizoctonia solani AG 1 ia from Latin America, Phytopath, 100 (2010) 172-182. Doi: https:// doi.org/10.1094/PHYTO-100-2-0172

Hossain M K, Jena K K, Bhuiyan M A \& Wickneswari $R_{\text {, (2016) Association between }}$ QTLS and morphological traits toward sheath blight resistance in rice (Oryza sativa L.), Breed. Sci, 66 613-626. doi: 10.1270/ jsbbs.15154

Kanno K, Suzuki Y \& Makino A, A Small (2017) Decrease in RuBisCO content by individual suppression of RBCS genes leads to improvement of photosynthesis and greater biomass production in rice under conditions of elevated CO2, Pt \& cell physiol, 58, 635-642. DOI: 10.1093 / pcp / pcX018

Karmakar S, Molla K A, Chanda P K, Sarkar S N,
Datta S K \& Datta K, (2016) Green tissuespecific co-expression of chitinase and oxalate oxidase 4 genes in rice for enhanced resistance against sheath blight, Planta, 243 115-130. DOI: 10.1007 / s00425-015-2398-x

Karmakar S, Molla K. A, Das K, Sarkar S. N, Datta S.K. (2017) Dual gene expression cassette is superior than single gene cassette for enhancing sheath blight tolerance in transgenic rice, Sci Rep, 7 (2017) 7900. doi: https://doi.org/10.1038/s41598-01708180-x

Kim DW, Rakwal R, Agrawal G K, Jung Y H, Shibato J (2005) hydroponic rice seedling culture model system for investigating proteome of salt stress in rice leaf. Electrophoresis, 26 (2005) 4521-4539. DOI: 10.1002 / elps.200500334

Kim S T, Kim S G, Hwang D H, Kang S Y, Kim H J, Lee B H, Lee J J \& Kang KY,(2004) Proteomic analysis of pathogen-responsive proteins from rice leaves induced by rice blast fungus Magnaporthe grisea, Proteomics 4 35693578. DOI: 10.1002 / pmic.200400999

Kouzai Y, Kimura M, Watanabe M, Kusunoki K, Osaka D (2018) Salicylic acid dependent immunity contributes to resistance against Rhizoctonia solani, a necrotrophic fungal agent of sheath blight, in rice and Brachypodium distachyon, New Phytol 217 771-783. DOI: 10.1002 / pmic.200400999

Lee J, Bricker T M, Lefevre M, Pinson S R \& Oard $\mathrm{J} H$, (2006) Proteomic and genetic approaches to identifying defence-related proteins in rice challenged with the fungal pathogen Rhizoctonia solani. Mol Pt Pathol, 7 (2006) 405-416. DOl: 10.1111 / j.13643703.2006.00350.x

Li Y, Zhang Z, Nie Y, Zhang L \& Wang Z, (2012) Proteomic analysis of salicylic acid-induced resistance to Magnaporthe oryzae in susceptible and resistant rice, Proteomics 
12 (2012) 2340-2354. DOI: 10.1002 / pmic.201200054

Liu F, Wang P, Zhang X, Li X, Yan X. et al, (2018) The genetic and molecular basis of crop height based on a rice model, Planta 247 (2018) 1-26. DOl: 10.1007 / s00425-0172798-1

Marín-Navarro J \& Moreno J, (2006) Cysteines 449 and 459 modulate the reductionoxidation conformational changes of ribulose 1.5-bisphosphate carboxylase/ oxygenase and the translocation of the enzyme to membranes during stress, Plant, cell \& environm, 29 (2006) 898-908. DOl: 10.1111 / j.1365-3040.2005.01469.x

Mathur S, Agrawal D \& Jajoo A, (2014) Photosynthesis: response to high temperature stress. J Photochem \& Photobiol B Biol, 137 116-126. DOI: 10.1016 / j.jphotobiol.2014.01.010

Merchante C, Stepanova A N \& Alonso J M, (2017) Translation regulation in plants: an interesting past, an exciting present and a promising future. Plant J Cell \& Molec Biol, 90 (2017) 628-653. DOI: 10.1111 / tpj.13520

Molla K A, Karmakar S, Chanda P K, Sarkar S N, Datta S K \& Datta K, (2016) Tissue specific expression of Arabidopsis NPR1 gene in rice for sheath blight resistance without compromising phenotypic cost, Plant Sci, 250 (2016) 105-114. DOl: 10.1016/ j.plantsci.2016.06.005

Molla K A, Karmakar S, Molla J, Bajaj P, Varshney R K et al, (2020) Understanding sheath blight resistance in rice: the road behind and the road ahead. Plant Biotechn J 18 (2020) 895915. DOI: 10.1111 / pbi.13312

Prathi N B, Palit P, Madhu P, M R, Laha G S et al, (2018) Proteomic and transcriptomic approaches to identify resistance and susceptibility related proteins in contrasting rice genotypes infected with fungal pathogen Rhizoctonia solani. Plant physiol \& biochem, 130 (2018) 258-266. DOI: 10.1016 / j.plaphy.2018.07.012

Richa K, Tiwari I M, Devanna B N, Botella J R, Sharma V \& Sharma T R, (2017) Novel chitinase gene LOC_Os11g47510 from indica rice Tetep provides enhanced resistance against sheath blight pathogen Rhizoctonia solani in rice, Front Plant Sci, 8 (2017) 596. DOl: 10.3389 / fpls.2017.00596

Taheri P \& Höfte M, (2007) Riboflavin-induced resistance against Rice Sheath Blight functions through the potentiation of lignin formation and jasmonic acid signalling pathway. Comm Agric \& Appl Biol Sci, 72 (2007) 309-313.

Wang $\mathrm{H}$, Meng J, Peng $\mathrm{X}$, Tang $\mathrm{X}$, Zhou $\mathrm{P}$ et al, (2015) Rice WRKY4 acts as a transcriptional activator mediating defense responses toward Rhizoctonia solani, the causing agent of rice sheath blight, Plant Mol Biol, 89: (2015) 157-171. DOl: 10.3389 / fpls.2017.00596

Wu Y, Mirzaei M, Pascovici D, Chick J M, Atwell B J \&Haynes PA, (2016) Quantitative proteomic analysis of two different rice varieties reveals that drought tolerance is correlated with reduced abundance of photosynthetic machinery and increased abundance of ClpD1 protease, J Proteomics, 143 (2016) 73-82. DOI: 10.1016 / j.jprot.2016.05.014

Yadav S, Anuradha G, Kumar R R, Vemireddy $L R$, Sudhakar $R$ et al, (2015) Identification of QTLs and possible candidate genes conferring sheath blight resistance in rice (Oryza sativa L.), Springerplus, 4 (2015) 175. DOI: 10.1186 / s40064-015-0954-2

Zhang F, Zeng D, Zhang C S, Lu J L, Chen T J et al, (2019) Genome-wide association analysis of the genetic basis for Sheath Blight Resistance in rice. Rice 12 (2019) 93. doi: 10.1186 / s12284-019-0351-5. 
Zhao C, Wang J, Cao M, Zhao K, Shao J et al, (2005) Proteomic changes in rice leaves during development of field-grown rice plants. Proteomics, 5 (2005) 961-972. doi: 10.1002 / pmic.200401131. 